\title{
PENGARUH FASILITAS KERJA, KEMAMPUAN DAN DISIPLIN KERJA TERHADAP KINERJA PEGAWAI PADA KANTOR KECAMATAN TINOMBO KABUPATEN PARIGI MOUTONG
}

\author{
Ani Khuryatul Abadiyah, S.E., M.M. \\ (Dosen Fakultas Perikanan Universitas Alkhairaat)
}

\begin{abstract}
ABSTRAK
Penelitian ini tentang pengaruh fasilitas kerja, kemampuan dan disiplin kerja terhadap kinerja pegawai pada Kantor Kecamatan Tinombo Kabupaten Parigi Moutong. Tujuan yang akan dicapai, fasilitas kerja, kemampuan dan disiplin kerja terhadap kinerja pegawai pada Kantor Kecamatan Tinombo Kabupaten Parigi Moutong. Penelitian dilakukan pada populasi adalah seluruh pegawai pada Kantor Kecamatan Tinombo Kabupaten Parigi Moutong, yang berjumlah 34 pegawai. Uji serempak adalah sebuah pengujian untuk mengetahui apakah variabel independen $(\mathrm{X})$ yang diteliti memiliki pengaruh terhadap variabel dependen (Y) berarti semua variabel bebasnya, yakni fasilitas kerja (X1), kemampuan (X2) dan disiplin kerja (X2) dengan variabel tidak bebasnya kinerja pegawai pada Kantor Kecamatan Tinombo Kabupaten Parigi Moutong. Dari tabel 4.8. terlihat hasil uji determinasi (kehandalan model) memperlihatkan nilai $R$ Square 0,923 atau $92.3 \%$. Hal ini berarti bahwa sebesar $92.3 \%$ variabel tidak bebas dipengaruhi oleh ketiga variabel bebas, selebihnya variabel tidak bebas dipengaruhi oleh variabel lain yang tidak diteliti. Selanjutnya berdasarkan tabel diatas dari hasil perhitungan diperoleh Fhitung $=53.527$ dan nilai Sig F $(0.000)<0,05$. Dengan demikian dapat dinyatakan bahwa secara serempak variabel bebas berpengaruh signifikan terhadap variabel tidak bebasnya. Dengan demikian maka hipotesis pertama yang menyatakan bahwa; fasilitas kerja, kemampuan dan disiplin kerja secara serempak berpengaruh signifikan terhadap kinerja pegawai pada Kantor Kecamatan Tinombo Kabupaten Parigi Moutong berdasarkan hasil uji-F ternyata terbukti.
\end{abstract}

Kata Kunci: Fasilitas, Kemampuan, Disiplin Kerja, Kinerja.

\section{LATAR BELAKANG}

Kepemimpinan (leadership) dapat dikatakan sebagai cara dari seorang pemimpin (leader), dalam mengarahkan, mendorong, dan mengatur semua unsur-unsur didalam suatu organisasi untuk mewujudkan suatu tujuan yang akan dicapai, sehingga menghasilkan kinerja pegawai yang maksimal. Dengan meningkatnya kinerja pegawai berarti tercapainya hasil kerja seseorang atau pegawai dalam mencapai tujuan organisasi. Menurut (Rahman, 2021) Organisasi tidak hanya semata-mata mengejar pencapaian produktifitas yang tinggi saja, tetapi juga lebih memperhatikan kinerja dalam proses pencapaian.

Menurut (Umar A, 2021), Tujuan didirikannya perusahaan adalah untuk mencari keuntungan yang layak untuk memelihara dan mempertahankan kelangsungan hidup perusahaan serta mengembangkan usaha. Untuk meraih tujuan tersebut harus di upayakan bagaimana cara seorang pemimpin dapat memberikan dorongan semangat kerja kepada karyawan, agar sasaran maupun tujuan yang di rencanakan secara bersama dapat mencapai target. Selain itu, pemimpin dapat memberikan promosi jabatan bagi karyawan yang berprestasi agar, terciptanya kepuasan kerja karyawan.

Selain memberikan promosi jabatan, seorang pemimipin harus memikirkan kesenangan terhadap karyawannya dengan memberikan gaji/upah yang sesuai, kemudian memberikan tunjangan setiap tahun, dan memberikan cuti. Menurut (Kaiyeli, 2021), Kompensasi dapat meningkatkan kinerja karyawan. Dengan memberikan kompensasi tersebut karyawan akan memiliki kepuasan kerja maupun semangat kerja yang tinggi untuk mencapai suatu target.

Dengan demikian, untuk menjadi pemimpin (leader) harus memiliki ambisi, tanggung jawab, mempunyai semangat yang tinggi untuk memberikan motivasi terhadap karyawan, kecerdasan, kedewasaan, keluasan hubungan sosial, dan berani dalam mengambil keputusan. Agar yang direncanakan oleh perusahaan tersebut dapat terealisasikan. 


\section{METODE PENELITIAN}

\section{Identifikasi variabel}

a. Adapun yang merupakan variabel bebas (X) adalah gaya kepemimpinan dengan sub-sub variabel:

$\left(\mathrm{X}_{1}\right)$ Tipe pemimpin paternalitas

$\left(\mathrm{X}_{2}\right)$ Tipe pemimpin otoriter

$\left(\mathrm{X}_{3}\right)$ Tipe pemimpin partisan

b. Variabel terikat (dependent) yaitu merupakan variabel yang dipengaruhi oleh variabel bebas. Adapun variabel terikat dalam penelitian ini adalah: Kepuasan kerja karyawan $(\mathrm{Y})$.

\section{Definisi konseptual variabel}

Variabel bebas (X), yaitu: Gaya kepemimpinan Sedangkan sub variabel gaya kepemimpinan dalam penelitian ini terdiri dari:

\section{Kemampuan Kerja}

Kemampuan kerja adalah suatu kapasitas individu untuk mengerjakan berbagai tugas dalam suatu pekerjaan (Robbins, 2006; 55). Salah satu faktor yang sangat penting dan berpengaruh terhadap keberhasilan karyawan di dalam melaksanakan suatu pekerjaan adalah kemampuan kerja. Dalam fungsi operasional manajemen kemampuan kerja merupakan fungsi pengembangan, karena dalam fungsi ini pengembangan kemampuan kerja karyawan sangat diperhatikan. Kemampuan kerja pada dasarnya sangat berpengaruh terhadap mutu atau bobot hasil kerja yang dicapai oleh seorang karyawan. Hal ini dapat dimengerti karena dalam kemampuan kerja terdapat berbagai potensi kecakapan, keterampilan, serta potensi yang lain yang mendukung yang tercermin dalam kondisi fisik dan psikis.

Kemampuan (ability) yang dimiliki karyawan bisa dikembangkan dan ditingkatkan melalui kegiatan pendidikan maupun pelatihan yang diberikan perusahaan tersebut, khususnya kemampuan yang dibutuhkan oleh perusahaan yang bersangkutan. Kemampuan kerja adalah keadaan tertentu yang ada pada diri seseorang yang dilakukan secara maksimal dan bersungguhsungguh dalam melakukan pekerjaan agar pekerjaannya tersebut berdaya dan berhasil guna (Ayu, 2013; 12).

Kemampuan seseorang akan ditentukan oleh tinggi rendahnya tingkat pendidikan dan pengalaman. Karena kedua unsur inilah pengetahuan dan keterampilan dapat diperoleh.
Jadi semakin tinggi tingkat pendidikan seseorang ditunjang dengan adanya pengalaman yang luas menunjukkan orang tersebut mempunyai tingkat kepuasan yang tinggi. Selain tingkat pendidikan dan pengalaman untuk meningkatkan kemampuan seseorang dapat ditempuh melalui pendidikan dan pelatihan, karena dengan adanya pendidikan dan pelatihan akan menambah pengetahuan seseorang untuk mengerjakan sesuatu bisa menjadi lebih cepat dan lebih baik. Dengan adanya latihanlatihan yang memungkinkan karyawan mendapatkan keterampilan lain yang lebih banyak, dengan demikian dapat meningkatkan pengetahuan mereka untuk mentransfer dan meningkatkan kecakapan kerja. Lebih lanjut Robbin (2006; 111) menjelaskan terdapat bermacam-macam jenis kamampuan antara lain:

1. Kemampuan intelektual

Kemampuan intelektual adalah kemampuan yang diperlukan untuk menjalankan kegiatan mental, seperti berpikir, menalar, dan memecahkan masalah.

2. Kemampuan kognitif

Kemampuan ini menunjukkan kapabilitas berkaitan dengan aplikasi pengetahuan dalam pemecahan masalah.

3. Kemampuan fisik

Kemampuan fisik adalah kemampuan yang diperlukan untuk melaksanakan tugas-tugas yang menuntut stamina, kecekatan, kekuatan dan keterampilan yang semacam.

4. Kemampuan emosional

Kemampuan ini lebih pada kemampuan seseorang dalam mengendalikan diri, sehingga ketika terjadi masalah tidak akan menggangu kinerjanya maupun orang lain yang ada disekitanya, dengan demikian orang tersebut dapat mengendalikan emosinya

\section{Disiplin}

Nitisemito (2001; 67) mengemukakan disiplin sebagai suatu sikap, perilaku dan perbuatan yang sesuai dengan peraturan dari perusahan, baik tertulis maupun tidak tertulis.. Secara etiomologis, "disiplin" berasal dari kata latin atau pendidikan kesopanan dan kerohanian serta pengembangan tabiat. Setelah diuraikan beberapa pengertian mengennai disiplin yang dikemukakan oleh beberapa ahli seperti tersebut diatas dapatlah dikatakan bahwa disiplin umumnya diartikan kepatuhan dan ketaatan pada peraturan-peraturan atau ketentuan-ketentuan 
yang berlaku dilingkungan organisasi masingmasing, jika terdapat pegawai yang tidak mematuhi segala peraturan dan ketentuan yang berlaku pada lingkungan kerjanya, berarti tindakan pegawai tersebut dapat dikategorikan sebagai tindakan yang melanggar disiplin.

Menurut Byars \& Rue (2005; 66), ada beberapa hal yang dapat dipakai sebagai indikasi tinggi rendahnya kedisplinan kerja karyawan, yaitu: ketepatan waktu, kepatuhan terhadap atasan, peraturan terhadap perilaku terlarang dan ketertiban terhadap peraturan yang berhubungan langsung dengan produktivitas kerja. Sedangkan De Cenzo dan Robbins (2009; 87) mengemukakan tipe permasalahan dalam kedisiplinan, antara lain kehadiran, perilaku dalam bekerja (dalam lingkungan kerja), ketidakjujuran aktivitas di luar lingkungan kerja. Menurut Harlie (2010; 27) indikator disiplin kerja adalah sebagai berikut:

1. Selalu mentaati ketentuan jam kerja.

2. Selalu menggunakan jam kerja dengan efektif dan efisien.

3. Memiliki semangat kerja yang tinggi.

4. Memiliki sikap dan kepribadian yang baik dengan menunjukkan keteladanan dalam melaksanakan tugas.

\section{Kinerja}

Bernardin dan Russsel (Sulistiyani dan Rosidah, 2003; 117) bahwa kinerja merupakan catatan outcome yang dihasilkan dari fungsi pegawai tertentu atau kegiatan yang dilakukan selama periode waktu tertentu. Sedang kinerja suatu jabatan secara keseluruhan sama dengan jumlah (rata-rata) dari kinerja fungsi pegawai atau kegiatan yang dilakukan. Pengertian kinerja di sini tidak bermaksud menilai karakteristik individu tetapi mengacu pada serangkaian hasil yang diperoleh selama periode waktu tertentu.

Rivai $(2005$; 60) mengemukakan kata kinerja, jika dilihat dari asal katanya adalah terjemahan dari kata performance yang berasal dari akar kata to perform yang berarti melaksanakan atau menyempurnakan tanggung jawab. Kinerja adalah hasil atau tingkat keberhasilan seseorang secara keseluruhan selama periode tertentu di dalam melaksanakan tugas dibandingkan dengan berbagai kemungkinan seperti standar hasil kerja, target atau sasaran atau kriteria yang telah ditentukan terlebih dahulu dan telah disepakati bersama. Byars dan Rue (2005; 113), mengatakan bahwa kinerja merupakan hasil dari usaha karyawan yang dipengaruhi oleh kemampuan dan persepsi peran (tugas). Dengan demikian, dalam situasi tertentu kinerja dapat dilihat sebagai hasil dari hubungan antara usaha, kemampuan dan persepsi tugas. Kinerja sangat dipengaruhi oleh beberapa faktor antara lain sebagai berikut :

1. Usaha

Merupakan hasil dari adanya motivasi, menunjukkan jumlah tenaga (fisik maupun mental) seseorang yang digunakan dalam melaksanakan tugas dan tanggung jawab dalam meningkatkan prestasi kerjanya.

2. Kemampuan

Merupakan kriteria seseorang yang digunakan dalam melaksanakan suatu pekerjaan.

3. Persepsi tugas

Menunjukkan arah dimana seseorang memahami kemana mereka seharusnya menyalurkan usahanya untuk keperluan pekerjaan mereka.

\section{Hubungan Antara Fasilitas Kerja Terhadap Kinerja}

Fasilitas kerja merupakan bagian penting dalam perusahaan. Kinerja karyawan sangat ditentukan oleh fasilitas yang diberikan guna menunjang pekerjaan karyawan untuk dapat menyelesaikan pekerjaannya. Di era globalisasi seperti ini fasilitas kerja memiliki peran penting dalam menentukan maju mundurnya sebuah perusahaan karena semakin banyak pekerjaan semakin banyak pula fasilitas yang dibutuhkan serta semakin modern fasilitas peralatan dan perlengkapan kantor yang diberikan kepada karyawan semakin optimal pula kinerja karyawan.

Menurut Moekijat (2007 : 155) secara sederhana yang dimaksud dengan fasilitas adalah suatu sarana fisik yang dapat memproses suatu masukan (input) menuju keluaran (output) yang diinginkan.

Dalam penelitian Almustofa (2013; 114) yang berjudul Pengaruh Pemberian Fasilitas, Tingkat Pendidikan Dan Disiplin Kerja Terhadap Peningkatan Kinerja Pegawai Pada Badan Pusat Statistik Kabupaten Maros yang menggunakan semua populasi menjadi sampel yaitu 30 orang karyawan pada koefesien $\mathrm{R}$ square menunjukan bahwa variabel fasilitas, pendidikan, dan disiplin berpengaruh sebesar $71,6 \%$ dan $28,4 \%$ dipengaruhi oleh variabel lain. 


\section{Hubungan Antara Kemampuan Kerja Terhadap Kinerja}

Dengan keterampilan yang ada maka pegawai akan berusaha meningkatkan kualitas dan kuantitas hasil kerjanya. Kemudian menurut pendapat Robbins (2006; 44) tingkat kinerja pegawai akan sangat tergantung pada faktor kemampuan kerja pegawai itu sendiri seperti tingkat pendidikan, pengetahuan, pengalaman dimana dengan tingkat kemampuan yang semakin tinggi akan mempunyai kinerja semakin tinggi pula. Dengan demikian tingkat pendidikan, pengetahuan dan pengalaman yang rendah akan berdampak negatif pada kinerja pegawai. Selanjutnya menurut Moenir (2000; 198-200) yang dimaksud dengan kemampuan dalam hubungan dengan pekerjaan adalah suatu keadaan pada seseorang yang secara penuh kesungguhan, berdayaguna dan berhasil guna melaksanakan pekerjaan sehingga menghasilkan sesuatu yang optimal. Kemampuan individu sebagai nilai yang dimiliki aparatur daerah menjadikan suatu kekuatan dalam menanggapi setiap kejadiankejadian atau persoalan dilingkungan pekerjaan. Kemampuan kerja individu yang terbentuk dengan baik akan memberikan pengaruh positif dengan kinerja organisasi (Wahyuningrum, 2008; 20).

Dari beberapa pendapat teori tersebut dapat disimpulkan bahwa kemampuan pegawai akan menentukan kinerja organisasi. Dengan demikiansemakin tinggi kemampuan kerja pegawai dalam melaksanakan pekerjaannya maka semakin tinggi kinerja pegawai.

\section{Hubungan Antara Disiplin Kerja Terhadap Kinerja}

Disiplin kerja mempunyai pengaruh positif terhadap kinerja karyawan. Karyawan yang disiplin dalam bekerja sejak berangkat, saat kerja dan saat pulang kerja serta sesuai aturan dalam bekerja, biasanya akan memiliki kinerja yang baik. Dapat disimpulkan, semakin tinggi disiplin kerja, maka semakin tinggi kinerja karyawan. Hasil penelitian Setiyawan dan Waridin (2006; 122) menunjukan bahwa disiplin berpengaruh terhadap kinerja karyawan.

Disiplin yang baik mencerminkan besarnya tanggung jawab seseorang terhadap tugas-tugas yang diberikan kepadanya. Seseorang dikatakan mempunyai disiplin kcrja yang tinggi jika yang bcrsangkutan konsekuen, konsisten, taat asas, bertanggung jawab atas tugas yang diamanahkan kepadanya. Disiplin kerja merupakan suatu alat yang digunakan para manajer untuk berkornunikasi dengan karyawan agar mereka bersedia untuk mengubah prilaku serta sebagai suatu upaya untuk meningkatkan kesadaran dan kesediaan seseorang mentaati semua peraturan perusahaan dan norma-norma sosial yang berlaku. Dengan disiplin kerja yang tinggi akan dapat membantu meningkatkan kinerja. Penelitian mengenai pengaruh disiplin kerja terhadap kinerja pernah dilakukan oleh Amran $(2009 ; 78)$ yang menghasilkan disiplin kerja berpengaruh positif dan signifikan terhadap kinerja.

\section{METODE PENELITIAN Populasi}

Menurut Sugiyono (2006; 23) populasi adalah wilayah generalisasi yang terdiri atas objek-objek yang mempunyai kualitas dan karakteristik tertentu yang ditetapkan oleh peneliti untuk dipelajari dan kemudian ditarik kesimpulannya. Dalam penelitian ini yang menjadi populasi adalah seluruh pegawai pada Kantor Kecamatan Tinombo Kabupaten Parigi Moutong, yang berjumlah 34 pegawai. Agar supaya penelitian ini dapat memberikan generalisasi dengan tingkat kesalahan yang sangat kecil, dan mengingat jumlah populasi hanya 34 pegawai, maka dalam penelitian ini mengambil seluruh populasi yaitu sampling jenuh (sensus), dimana semua anggota populasi dijadikan sampel.

\section{Defenisi Operasional Variabel}

Untuk memperjelas variabel-variabel yang digunakan dalam penelitian ini, dikemukakan batasan-batasan definisi operasional yang akan digunakan sebagai bahan acuan dan dijabarkan dalam bentuk kuesioner. Variabel-variabel sebagai berikut:

1. Fasilitas kerja.

Menurut Moekijat (2001 : 155) secara sederhana yang dimaksud dengan fasilitas adalah suatu sarana fisik yang dapat memproses suatu masukan (input) menuju keluaran (output) yang diinginkan. Menurut Moenir (2000; 198-200) dari pengertian fasilitas di atas maka dapat dibagi dua golongan besar yaitu fasilitas alat kerja dan fasilitas perlengkapan kerja.

2. Kemampuan.

Definisi kemampuan kerja dalam penelitian ini adalah suatu kapasitas individu pegawai pada Kantor Kecamatan Tinombo 
Kabupaten Parigi Moutong untuk mengerjakan berbagai tugas dalam suatu pekerjaan. Dalam penelitian ini penulis menggunakan indikator dari Robbin (2006; 111) menjelaskan terdapat bermacammacam jenis kamampuan antara lain:

a. Kemampuan intelektual.

b. Kemampuan kognitif.

c. Kemampuan fisik.

d. Kemampuan emosional.

3. Disiplin Kerja

Definisi disiplin kerja dalam penelitian ini adalah suatu sikap, perilaku dan perbuatan yang sesuai dengan peraturan dari perusahan, baik tertulis maupun tidak tertulis pada Kantor Kecamatan Tinombo Kabupaten Parigi Moutong. Menurut Harlie (2010; 27) indikator disiplin kerja adalah sebagai berikut:

a. Selalu mentaati ketentuan jam kerja.

b. Selalu menggunakan jam kerja dengan efektif dan efisien.

c. Memiliki semangat kerja yang tinggi.

d. Memiliki sikap dan kepribadian yang baik dengan menunjukkan keteladanan dalam melaksanakan tugas.

4. Kinerja

Definisi kinerja pegawai dalam penelitian ini adalah hasil dari usaha pegawai pada Kantor Kecamatan Tinombo Kabupaten Parigi Moutong. Byars dan Rue (2005; 113), mengatakan bahwa kinerja merupakan hasil dari usaha karyawan yang dipengaruhi oleh kemampuan dan persepsi peran (tugas).

\section{Uji Validitas}

Seperti yang dikemukakan oleh Sugiyono $(2006 ; 89)$ bahwa instrumen yang valid berarti alat ukur yang digunakan untuk mendapatkan data itu valid. Validitas dapat diketahui dengan cara membandingkan nilai corrected item-total correlation dengan nilai rkritis sesuai kriteria. Menurut Sugiyono (2006; 18), bahwa bilamana koefisien antara skor suatu indikator dengan skor total seluruh indikator adalah positif dan lebih besar $0,3 \quad(r \geq 0,3)$ maka instrument tersebut dianggap valid. Berdasarkan hasil analisis dengan bantuan program SPSS 16.00 telah dilakukan melalui pengujian statistik terhadap variabel fasilitas kerja (X1), kemampuan (X2) dan disiplin (X3) terhadap kinerja (Y) secara keseluruhan item pernyataan dinyatakan valid karena seluruh nilai corrected item-total correlation lebih besar dari nilai 0.3 .

\section{Uji Reliabilitas}

Instrumen penelitian selain valid, juga harus dapat diandalkan (reliable), instrumen dapat dikatakan reliabel jika alat tersebut menghasilkan nilai-nilai yang konsisten dengan demikian instrumen ini dapat dipakai dengan aman karena dapat bekerja dengan baik pada waktu yang berbeda dengan kondisi yang berbeda (Sugiyono, 2006; 46). Dalam penelitian ini dilakukan uji reliabilitas internal dengan menggunkan koefisien alpha cronbach $(\alpha)$. Suatu instrumen disebut reliabel apabila alpha cronbach lebih besar dari 0,60 (Sugiyono, 2006; 44). Hasil analisis dengan bantuan program SPSS 16.00 yang telah dilakukan pengujian statistik terhadap variabel fasilitas kerja (X1), kemampuan (X2) dan disiplin (X3) terhadap kinerja (Y) dapat dilihat pada tabel berikut:

Tabel 1. Hasil Uji Reliabilitas

\begin{tabular}{|c|c|c|}
\hline Variabel & $\begin{array}{c}\text { Alpha } \\
\text { Cronbach }\end{array}$ & Keterangan \\
\hline Fasilitas Kerja $\left(\mathrm{X}_{1}\right)$ & 0.836 & Reliable \\
\hline Kemampuan $\left(\mathrm{X}_{2}\right)$ & 0.803 & Reliable \\
\hline Disiplin $\left(\mathrm{X}_{3}\right)$ & 0.839 & Reliable \\
\hline Kinerja $(\mathrm{Y})$ & 0.846 & Reliable \\
\hline
\end{tabular}

\section{Uji Asumsi Klasik}

1. Uji Normalitas.

Model regresi yang baik adalah distribusi data normal atau mendekati normal. Menurut Ghozali (2005; 108) deteksi normalitas dilakukan dengan melihat penyebaran data (titik) pada sumbu diagonal dari grafik.

Dengan menggunakan bantuan program statistik hasil uji normalitas data pada penelitian ini dapat dilihat pada grafik (gambar) di bawah ini:

\section{Gambar 1. Hasil Uji Normalitas}

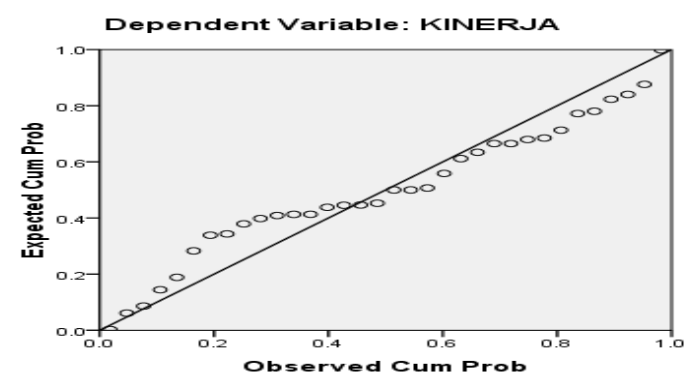


Pada gambar tersebut memperlihatkan bahwa sebaran data mengikuti garis diagonal. Berdasarkan hal tersebut, maka dapat disimpulkan bahwa data yang digunakan dalam analisis regresi ini terdistribusi dengan normal.

2. Uji Multikolinearitas.

Model regresi yang baik seharusnya tidak terjadi korelasi diantara variabel independen. Menurut Ghozali (2005; 105): untuk mengetahuinya adanya multikolinearitas dengan melihat nilai Variance Inflation Factor (VIF). Nilai toleran yang lebih besar dari 0,10 atau nilai VIF lebih kecil dari 10, maka terjadi multikolinearitas. Hasil uji multikolinearitas dengan menggunakan VIF dan tolerance seperti pada tabel berikut:

Tabel 2. Hasil Uji Multikolinearitas

\begin{tabular}{|c|c|c|c|}
\hline \multirow{2}{*}{ No } & \multirow{2}{*}{ Variabel } & \multicolumn{2}{c|}{$\begin{array}{c}\text { Collinearity } \\
\text { Statistics }\end{array}$} \\
\cline { 3 - 4 } & & VIF & Tolerance \\
\hline 1 & Fasilitas Kerja $\left(\mathrm{X}_{1}\right)$ & 4.128 & 0.242 \\
\hline 2 & Kemampuan $\left(\mathrm{X}_{2}\right)$ & 2.340 & 0.427 \\
\hline 3 & Disiplin $\left(\mathrm{X}_{3}\right)$ & 6.214 & 0.161 \\
\hline
\end{tabular}

3. Uji Heteroskedastisitas.

Uji heterokedastisitas bertujuan untuk mengetahui apakah variabel pengganggu (distrubance error) mempunyai varians konstan. Uji ini juga untuk menguji apakah dalam model regresi terjadi ketidaksamaan variance dari residual satu pengamatan ke pengamatan lainnya.

Menurut Imam Ghozali (2005; 105) untuk menguji asumsi ini dilakukan dengan melihat grafik scaterplot antara nilai prediksi variabel terikat (ZPRED) dengan variabel bebas (SRESID) dengan residualnya.

Hasil uji heterokedastisitas dari model regresi yang terbentuk tersaji pada gambar berikut:

Gambar 2. Hasil Uji Heteroskedastisitas

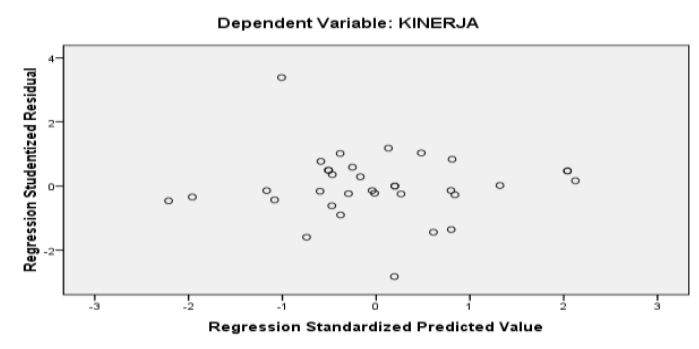

Berdasarkan Gambar di atas terlihat titiktitik menyebar secara acak, tidak membentuk sebuah pola tertentu yang jelas, serta tersebar baik di atas maupun dibawah angka 0 pada sumbu Y. Hal ini memberi makna bahwa persamaan regresi memenuhi asumsi heteroskedastisitas.

\section{HASIL DAN PEMBAHASAN Hasil Pengujian Regresi}

Sesuai hasil analisis Regresi Linear Berganda dengan menggunakan bantuan komputer SPSS For Wind Release 16.0 diperoleh hasil-hasil penelitian dari 34 orang responden dengan dugaan pengaruh ketiga variabel independen (fasilitas kerja, kemampuan dan disiplin kerja) terhadap kinerja pegawai pada Kantor Kecamatan Tinombo Kabupaten Parigi Moutong dapat diketahui hasil perhitungan sebagai berikut:

Tabel 2. Hasil Uji Regresi

\begin{tabular}{|c|c|c|c|}
\hline No & Variabel & $\begin{array}{c}\text { Unstandar } \\
\text { dized } \\
\text { Coefficien } \\
\text { ts }\end{array}$ & Sig \\
\hline 1 & Constanta & -0.548 & \\
\hline 2 & Fasilitas Kerja $\left(\mathrm{X}_{1}\right)$ & 0.540 & 0.001 \\
\hline 3 & Kemampuan $\left(\mathrm{X}_{2}\right)$ & 0.524 & 0.000 \\
\hline 4 & Disiplin Kerja $\left(\mathrm{X}_{3}\right)$ & 0.224 & 0.043 \\
\hline $\begin{array}{l}\mathrm{R} \\
\text { F Hitung } ; 0.961\end{array}$ & \\
R Square $; 0.923$ & & \\
Sig F $; 0.000$ & & \\
\hline
\end{tabular}
diatas adalah:

Model regresi yang diperoleh dari tabel

$$
\mathrm{Y}=\mathbf{- 0 . 5 4 8}+\mathbf{0 . 5 4 0 X 1}+\mathbf{0 . 5 2 4 X 2}+\mathbf{0 . 2 2 4 X 3}
$$

Persamaan diatas menunjukkan, variabel independen yang dianalisis berupa variabel $(\mathrm{X} 1$, $\mathrm{X} 2$ dan $\mathrm{X} 3$ ) memberi pengaruh terhadap variabel independen (Y). Dari persamaan di atas dapat dijelaskan:

1. Untuk nilai constanta sebesar -0.548 berarti kinerja pegawai pada Kantor Kecamatan Tinombo Kabupaten Parigi Moutong sebelum adanya variabel independen adalah sebesar -0.548 .

2. Fasilitas Kerja (X1) dengan koefisien regresi 0.540 ini berarti terjadi pengaruh yang positif antara fasilitas kerja dan kinerja pegawai pada Kantor Kecamatan Tinombo Kabupaten Parigi Moutong. Artinya jika 
fasilitas kerja yang dimiliki pegawai meningkat maka akan menaikkan kinerja pegawai pada Kantor Kecamatan Tinombo Kabupaten Parigi Moutong sebesar $54.0 \%$ dengan asumsi variabel kemampuan dan disiplin kerja (X2 dan X3) tetap.

3. Kemampuan (X2) dengan koefisien regresi 0.524 ini berarti terjadi pengaruh yang positif antara kemampuan dan kinerja pegawai pada Kantor Kecamatan Tinombo Kabupaten Parigi Moutong. Artinya jika kemampuan kerja yang dimiliki pegawai meningkat maka akan menaikkan kinerja pegawai pada Kantor Kecamatan Tinombo Kabupaten Parigi Moutong sebesar 52.4\% dengan asumsi variabel fasilitas kerja dan disiplin kerja (X1 dan X3) tetap.

4. Disiplin kerja (X2) dengan koefisien regresi 0.224 ini berarti terjadi pengaruh yang positif antara disiplin kerja dan kinerja pegawai pada Kantor Kecamatan Tinombo Kabupaten Parigi Moutong. Artinya jika sikap disiplin pegawai meningkat maka akan menaikkan kinerja pegawai pada Kantor Kecamatan Tinombo Kabupaten Parigi Moutong sebesar $22.4 \%$ dengan asumsi variabel fasilitas kerja dan kemampuan (X1 dan X2) tetap.

\section{Pengujian Hipotesis Pertama}

Uji serempak adalah sebuah pengujian untuk mengetahui apakah variabel independen (X) yang diteliti memiliki pengaruh terhadap variabel dependen (Y) berarti semua variabel bebasnya, yakni fasilitas kerja (X1), kemampuan (X2) dan disiplin kerja (X2) dengan variabel tidak bebasnya kinerja pegawai pada Kantor Kecamatan Tinombo Kabupaten Parigi Moutong. Dari tabel 4.8. terlihat hasil uji determinasi (kehandalan model) memperlihatkan nilai $R$-Square 0,923 atau $92.3 \%$. Hal ini berarti bahwa sebesar $92.3 \%$ variabel tidak bebas dipengaruhi oleh ketiga variabel bebas, selebihnya variabel tidak bebas dipengaruhi oleh variabel lain yang tidak diteliti.

Selanjutnya berdasarkan tabel diatas dari hasil perhitungan diperoleh Fhitung $=53.527$ dan nilai Sig F (0.000) < 0,05. Dengan demikian dapat dinyatakan bahwa secara serempak variabel bebas berpengaruh signifikan terhadap variabel tidak bebasnya. Dengan demikian maka hipotesis pertama yang menyatakan bahwa; fasilitas kerja, kemampuan dan disiplin kerja secara serempak berpengaruh signifikan terhadap kinerja pegawai pada Kantor Kecamatan Tinombo Kabupaten Parigi Moutong berdasarkan hasil uji-F ternyata terbukti.

\section{Pengujian Hipotesis Kedua}

Untuk variabel fasilitas kerja, hasil perhitungannya menunjukkan bahwa nilai koefisien regresi sebesar 0.540 , sementara nilai signifikasi t sebesar 0,001. Dengan demikian nilai Sig $\mathrm{t}<0,05$ pada taraf kepercayaan $95 \%$. Sehingga dapat dinyatakan bahwa variabel fasilitas kerja berpengaruh signifikan terhadap kinerja pegawai pada Kantor Kecamatan Tinombo Kabupaten Parigi Moutong. Maka hipotesis kedua yang menyatakan bahwa; fasilitas kerja berpengaruh positif dan signifikan terhadap kinerja pegawai pada Kantor Kecamatan Tinombo Kabupaten Parigi Moutong, berdasarkan hasil uji-t ternyata terbukti.

\section{Pengujian Hipotesis Ketiga}

Untuk variabel kemampuan, hasil perhitungannya menunjukkan bahwa nilai koefisien regresi sebesar 0.524 , sementara nilai signifikasi t sebesar 0,000. Dengan demikian nilai Sig $\mathrm{t}<0,05$ pada taraf kepercayaan $95 \%$. Sehingga dapat dinyatakan bahwa variabel kemampuan berpengaruh signifikan terhadap kinerja pegawai pada Kantor Kecamatan Tinombo Kabupaten Parigi Moutong. Maka hipotesis ketiga yang menyatakan bahwa; kemampuan berpengaruh positif dan signifikan terhadap kinerja pegawai pada Kantor Kecamatan Tinombo Kabupaten Parigi Moutong, berdasarkan hasil uji-t ternyata terbukti.

\section{Pengujian Hipotesis Keempat}

Untuk variabel disiplin kerja, hasil perhitungannya menunjukkan bahwa nilai koefisien regresi sebesar 0.224 , sementara nilai signifikasi t sebesar 0,043. Dengan demikian nilai Sig $\mathrm{t}<0,05$ pada taraf kepercayaan $95 \%$. Sehingga dapat dinyatakan bahwa variabel disiplin kerja berpengaruh signifikan terhadap kinerja pegawai pada Kantor Kecamatan Tinombo Kabupaten Parigi Moutong. Maka hipotesis keempat yang menyatakan bahwa; disiplin kerja berpengaruh positif dan signifikan terhadap kinerja pegawai pada Kantor Kecamatan Tinombo Kabupaten Parigi Moutong, berdasarkan hasil uji-t ternyata terbukti. 


\section{Pembahasan}

Berdasarkan hasil analisis data yang telah diuraikan sebelumnya, menujukkan bahwa variabel fasilitas kerja, kemampuan dan disiplin kerja secara serempak berpengaruh signifikan terhadap kinerja pegawai pada Kantor Kecamatan Tinombo Kabupaten Parigi Moutong. Hasil tersebut mengindikasikan bahwa fasilitas kerja, kemampuan dan disiplin kerja dapat meningkatkan kinerja pegawai pada Kantor Kecamatan Tinombo Kabupaten Parigi Moutong, hal ini bermakna bahwa semua hipotesis yang diuraikan sebelumnya sejalan dengan hasil penelitian ini.

Fasilitas kerja merupakan sarana penunjang bagi pegawai untuk melakukan pekerjaan yang diberikan kepadanya. Lupiyaodi (2008 : 150), fasilitas adalah sarana pendukung dalam aktivitas perusahaan yang berbentuk fisik, dan digunakan dalam kegiatan normal, memiliki jangka waktu kegunaan yang relatif permanen dan memberikan manfaat dimasa yang akan datang.

Apabila ingin mencapai hasil yang maksimal seorang pegawai harus bekerja dengan sungguh-sungguh beserta segenap kemampuan yang dimiliki ditunjang oleh sarana dan prasarana yang ada. Jika seorang pegawai bekerja dengan setengah hati maka pekerjaan yang dihasilkan tidaklah semaksimal yang diharapkan. Artinya bahwa kemampuan seseorang bisa diukur dari tingkat keterampilan dan pengetahuan yang dimiliki dalam melaksanakan tugas yang dibebankan.

Dengan keterampilan yang ada maka pegawai akan berusaha meningkatkan kualitas dan kuantitas hasil kerjanya. Kemudian menurut pendapat Robbins (2006; 55) tingkat kinerja pegawai akan sangat tergantung pada faktor kemampuan kerja pegawai itu sendiri seperti tingkat pendidikan, pengetahuan, pengalaman dimana dengan tingkat kemampuan yang semakin tinggi akan mempunyai kinerja semakin tinggi pula. Dengan demikian tingkat pendidikan, pengetahuan dan pengalaman yang rendah akan berdampak negatif pada kinerja pegawai. Selanjutnya menurut Moenir (2000; 195) yang dimaksud dengan kemampuan dalam hubungan dengan pekerjaan adalah suatu keadaan pada seseorang yang secara penuh kesungguhan, berdayaguna dan berhasil guna melaksanakan pekerjaan sehingga menghasilkan sesuatu yang optimal. Kemampuan individu sebagai nilai yang dimiliki aparatur daerah menjadikan suatu kekuatan dalam menanggapi setiap kejadiankejadian atau persoalan dilingkungan pekerjaan. Kemampuan kerja individu yang terbentuk dengan baik akan memberikan pengaruh positif dengan kinerja organisasi (Wahyuningrum, 2008; 78).

Disiplin kerja mempunyai pengaruh positif terhadap kinerja karyawan. Karyawan yang disiplin dalam bekerja sejak berangkat, saat kerja dan saat pulang kerja serta sesuai aturan dalam bekerja, biasanya akan memiliki kinerja yang baik. Dapat disimpulkan, semakin tinggi disiplin kerja, maka semakin tinggi kinerja karyawan. Disiplin yang baik mencerminkan besarnya tanggung jawab seseorang terhadap tugas-tugas yang diberikan kepadanya. Seseorang dikatakan mempunyai disiplin kcrja yang tinggi jika yang bcrsangkutan konsekuen, konsisten, taat asas, bertanggung jawab atas tugas yang diamanahkan kepadanya. Disiplin kerja merupakan suatu alat yang digunakan para manajer untuk berkornunikasi dengan karyawan agar mereka bersedia untuk mengubah prilaku serta sebagai suatu upaya untuk meningkatkan kesadaran dan kesediaan seseorang mentaati semua peraturan perusahaan dan norma-norma sosial yang berlaku. Dengan disiplin kerja yang tinggi akan dapat membantu meningkatkan kinerja.

\section{Pengaruh Fasilitas Kerja Terhadap Kinerja Pegawai Pada Kantor Kecamatan Tinombo Kabupaten Parigi Moutong.}

Hasil pengujian hipotesis telah membuktikan bahwa fasilitas berpengaruh positif dan signifikan terhadap kinerja. Artinya bahwa ada pengaruh antara variabel fasilitas kerja terhadap kinerja pegawai pada Kantor Kecamatan Tinombo Kabupaten Parigi Moutong, dengan kata lain bila fasilitas kerja yang dimiliki pegawai baik akan meningkatkan kinerja pegawai pada Kantor Kecamatan Tinombo Kabupaten Parigi Moutong, sebaliknya bila fasilitas kerja yang dimiliki pegawai rendah/buruk maka kinerja pegawai pada Kantor Kecamatan Tinombo Kabupaten Parigi Moutong akan menurun.

Fasilitas kerja merupakan bagian penting dalam perusahaan. Kinerja karyawan sangat ditentukan oleh fasilitas yang diberikan guna menunjang pekerjaan karyawan untuk dapat menyelesaikan pekerjaannya. Di era globalisasi seperti ini fasilitas kerja memiliki peran penting dalam menentukan maju mundurnya sebuah perusahaan karena semakin banyak pekerjaan semakin banyak pula fasilitas yang dibutuhkan 
serta semakin modern fasilitas peralatan dan perlengkapan kantor yang diberikan kepada karyawan semakin optimal pula kinerja karyawan.

Dalam penelitian Almustofa $(2013 ; 114)$ yang berjudul Pengaruh Pemberian Fasilitas, Tingkat Pendidikan Dan Disiplin Kerja Terhadap Peningkatan Kinerja Pegawai Pada Badan Pusat Statistik Kabupaten Maros yang menggunakan semua populasi menjadi sampel yaitu 30 orang karyawan pada koefesien $\mathrm{R}$ square menunjukan bahwa variabel fasilitas, pendidikan, dan disiplin berpengaruh sebesar $71,6 \%$ dan $28,4 \%$ dipengaruhi oleh variabel lain.

\section{Pengaruh Kemampuan Terhadap Kinerja Pegawai Pada Kantor Kecamatan Tinombo Kabupaten Parigi Moutong.}

Hasil pengujian hipotesis telah membuktikan bahwa kemampuan berpengaruh positif dan signifikan terhadap kinerja. Artinya bahwa ada pengaruh antara variabel kemampuan terhadap kinerja pegawai pada Kantor Kecamatan Tinombo Kabupaten Parigi Moutong, dengan kata lain bila kemampuan yang dimiliki pegawai baik akan meningkatkan kinerja pegawai pada Kantor Kecamatan Tinombo Kabupaten Parigi Moutong, sebaliknya bila kemampuan yang dimiliki pegawai rendah/buruk maka kinerja pegawai pada Kantor Kecamatan Tinombo Kabupaten Parigi Moutong akan menurun.

Hal ini mengindikasikan bahwa pegawai pada Kantor Kecamatan Tinombo Kabupaten Parigi Moutong memiliki kemampuan dalam hal mengumpulkan atau memperolah sebuah informasi. Lalu bagaimana pegawai tersebut menyatukan informasi itu dalam pemahamannya, setelah itu bagaimana pegawai tersebut mengintepretasikan atau mentransfer informasi tersebut kepada pegawai lain. Kemampuan kognitif adalah kemampuan seseorang dalam memproses satu atau lebih informasi, dimana proses dalam hal ini menyangkut juga mengenai pemahaman orang tersebut tehadap informasi yang dia dapatkan. kemampuan kognitif adalah kemampuan untuk mengidentifikasi informasiinformasi kunci dari sebuah permasalahan adalah hal yang sangat penting untuk sebuah pengambilan keputusan bagi seorang manajer. Dari hal tersebut dapat dikatakan juga menganggap kemampuan kognitif sangat berkaitan dengan kemampuan seseorang dalam menyaring dan mendapatkan informasi kunci dari sebuah kejadian. Data diatas menjelaskan bahwa para pegawai pada Kantor Kecamatan Tinombo Kabupaten Parigi Moutong dalam mengambil keputusan terkait pekerjaan tidak tergesa-gesa, karena keputusan yang dibuat tergesa-gesa tanpa menganalisa lebih jauh dapat menimbulkan masalah dikemudian hari.

Hasil penelitian ini sejalan dengan penelitian yang dilakukan Yani (2013), tentang Analisis Pengaruh Kepemimpinan, Lingkungan, Motivasi, Dan Kemampuan Kerja Terhadap Kinerja Karyawan. Hasil penelitian menunjukkan Seluruh faktor Kepemimpinan, Lingkungan kerja, Motivasi dan Kemampuan kerja secara parsial berpengaruh terhadap kinerja pegawai PT. Pertani (Persero) Area Pemasaran Sulawesi.

\section{Pengaruh Disiplin Kerja Terhadap Kinerja Pegawai Pada Kantor Kecamatan Tinombo Kabupaten Parigi Moutong}

Hasil pengujian hipotesis telah membuktikan bahwa disiplin kerja berpengaruh positif dan signifikan terhadap kinerja. Artinya bahwa ada pengaruh antara variabel disiplin kerja terhadap kinerja pegawai pada Kantor Kecamatan Tinombo Kabupaten Parigi Moutong, dengan kata lain bila sikap disiplin yang dimiliki pegawai baik akan meningkatkan kinerja pegawai pada Kantor Kecamatan Tinombo Kabupaten Parigi Moutong, sebaliknya bila sikap disiplin yang dimiliki pegawai rendah/buruk maka kinerja pegawai pada Kantor Kecamatan Tinombo Kabupaten Parigi Moutong akan menurun.

Kantor Kecamatan Tinombo Kabupaten Parigi Moutong perlu memperhatikan disiplin kerja yaitu dengan memberikan perhatian setiap hari kerja atau dikontrol dan pemberian penghargaan kepada karyawan yang teladan dalam bekerja. Hal ini dilakukan agar karyawan lebih bersemangat dalam bekerja, sehingga meningkatkan kinerja pegawai. disiplin kerja merupakan salah satu hal yang penting bagi Kantor Kecamatan Tinombo Kabupaten Parigi Moutong terutama yang menyangkut kinerja pegawai Kantor Kecamatan Tinombo Kabupaten Parigi Moutong. Disiplin kerja pada hakekatnya merupakan perwujudan dari moral yang tinggi, bahkan ada yang mengidentifikasikan atau menterjemahkan secara bebas bahwa moral kerja yang tinggi adalah disiplin kerja. Dengan disiplin kerja yang tinggi, maka kinerja akan meningkat karena para pegawai akan melakukan pekerjaan secara lebih giat sehingga pekerjaan dapat diharapkan lebih cepat 
dan lebih baik. Begitu juga sebaliknya jika semangat kerja turun maka kinerja akan turun juga. Jadi dengan kata lain disiplin kerja akan berpengaruh terhadap kinerja karyawan. Disiplin kerja adalah keinginan dan kesungguhan seseorang mengerjakan pekerjaannya dengan baik serta berdisiplin untuk mencapai prestasi kerja yang maksimal.

Hasil penelitian ini sejalan dengan penelitian yang dilakukan Setiyawan dan Waridin (2006) menunjukan bahwa disiplin berpengaruh terhadap kinerja karyawan. Penelitian mengenai pengaruh disiplin kerja terhadap kinerja pernah dilakukan oleh Amran (2009; 78) yang menghasilkan disiplin kerja berpengaruh positif dan signifikan terhadap kinerja.

\section{KESIMPULAN \\ Kesimpulan}

Berdasarkan hasil pembahasan dan hasil olahan data pada penelitian ini, maka kesimpulan yang dapat ditarik adalah sebagai berikut:

1. Hasil pengujian hipotesis, menyimpulkan bahwa fasilitas kerja (X1) , kemampuan (X2) dan disiplin kerja (X3), terbukti berpengaruh signifikan secara serempak terhadap kinerja pegawai pada Kantor Kecamatan Tinombo Kabupaten Parigi Moutong.

2. Hasil analisis regresi menunjukkan bahwa variabel fasilitas kerja berpengaruh signifikan terhadap kinerja pegawai pada Kantor Kecamatan Tinombo Kabupaten Parigi Moutong.

3. Hasil analisis regresi menunjukkan bahwa variabel kemampuan berpengaruh signifikan terhadap kinerja pegawai pada Kantor Kecamatan Tinombo Kabupaten Parigi Moutong.

4. Hasil analisis regresi menunjukkan bahwa variabel disiplin kerja signifikan terhadap kinerja pegawai pada Kantor Kecamatan Tinombo Kabupaten Parigi Moutong.

\section{Saran}

Adapun saran-saran yang dapat diajukan dalam penelitian ini dengan melihat hasil pembahasan penelitian adalah sebagai berikut:

1. Dalam rangka meningkatkan kinerja pada Kantor Kecamatan Tinombo Kabupaten Parigi Moutong perlu berdasarkan variabel fasilitas kerja, maka pimpinan dapat meningkatkan fasilitas kantor, agar semua pegawai dapat menggunakan fasilitas kantor dalam rangka mencapai kinerja yang lebih baik.

2. Kantor Kecamatan Tinombo Kabupaten Parigi Moutong perlu melakukan upaya peningkatan kemampuan terhadap pegawai yang dapat dilakukan melalui pendidikan dan pelatihan-pelatihan yang disesuaikan dengan tiap tupoksi masing-masing pegawai baik yang diselenggarakan oleh instansi tersebut atau dari instansi yang lain, dan pemberian pelatihan ketrampilan dalam menggunakan peralatan kantor secara optimal sehingga meningkatkan kemampuan pegawai dalam pelaksanaan administrasi perkantoran, serta dapat melalui peningkatan motivasi pegawai dalam bekerja.

3. Kantor Kecamatan Tinombo Kabupaten Parigi Moutong sebaiknya lebih meningkatkan tingkat disiplin pada pegawai. Pemimpin sebaiknya perlu mengawasi, menegakkan peraturan dan memberikan sanksi yang tegas untuk pegawai, supaya pegawai dapat lebih disiplin, rajin dan efektif menggunakan waktu kerjanya untuk melakukan pekerjaannya.

4. Bagi peneliti selanjutnya, walaupun pada penelitian ini jumlah sampel memenuhi syarat penelitian, pada penelitian selanjutnya disarankan untuk menggunakan sampel dengan jumlah yang lebih banyak, sehingga hasil jawaban yang diambil bisa lebih bervariasi dan hendaknya melibatkan lebih banyak lagi variabel bebas, serta lebih memperdalam analisisnya pada peramalan kinerja di masa mendatang.

\section{DAFTAR PUSTAKA}

Almustofa, Resa. 2013. Pengaruh Lingkungan Kerja, Motivasi Kerja, Disiplin Kerja Terhadap Kinerja Pegawai (Studi Pada Pegawai Perum Bulog Divisi Regional Jakarta). Skripsi. Semarang: Fakultas Ekonomika Dan Bisnis Universitas Diponegoro.

Amran. 2009. Pengaruh Disiplin Kerja Terhadap Kinerja Pegawai Kantor Departemen Sosial Kabupaten Gorontalo. Jurnal Ichsan Gorontalo. Vol. 4 No.2 Hal. 10-17.

Ayu, Diah. 2013. Pengaruh Kemampuan Kerja dan Motivasi Kerja Terhadap Kinerja Karyawan Pada Karyawan Operator PT. Indonesia Power Unit Bisnis Pembangkitan 
Semarang. Jurnal Ilmu Adminsitrasi Bisnis. Vol. 2 No.1 hal. 1-7.

Byars, Lyold L. and Rue, Leslie W. 2005. Human Resources Management. Mc Graw Hill International Editions.

De cenzo and Robbins, Stephen P. 2009, Perilaku Organisasi Konsep, Kontroversi dan Aplikasi. Diterjemahkan oleh Hadyana Pujaatmaka. Jakarta: Prenhallindo.

Ghozali, Imam. 2005, Analisis Multivariate dengan Program SPSS. Semarang; Badan Penerbit Universitas Diponegoro.

Harlie, M. 2010. Pengaruh Disiplin Kerja, Motivasi dan Pengembangan Karier Terhadap Kinerja Pegawai Negeri Sipil Pada Pemerintah Kabupaten Tabalong di Tanjung Kalimantan Selatan. Jurnal Manajemen dan Akuntansi. Vol.11 No.2: Hal.118

Kaiyeli, N. (2021). PENGARUH KOMPENSASI, PENGALAMAN KERJA DAN KOMITMEN ORGANISASI TERHADAP KINERJA PEGAWAI NEGERI SIPIL (PNS) PADA DINAS PEKERJAAN UMUM DAERAH KABUPATEN SIGI. Jurnal Ekonomi Trend, 7(1), 41-57. https://doi.org/10.31970/trend.v7i1.172

Lupiyoadi, Rambat. 2001. Manajemen Pemasaran Jasa: Teori dan praktik. Jakarta: PT. Salemba Emban Patria

Malthis, Robert L. Jackson, 2006. Manajemen Sumber Daya Manusia, Jakarta: Salemba.

Maslow, A.H. 2004. Motivasi dan Kepribadian: Teori Motivasi dengan Ancaman Hierarki Kebutuhan Manusia. Jakarta: Pustaka Binangun Prestindo.

Moenir. 2000. Pendekatan Manusia dan Organisasi terhadap Pembinaan Kepegawaian. Jakarta: Gunung Agung.

Nitisemito, Alex S. 2001. Manajemen Personalia: Manajemen Sumber Daya. Manusia. Jakarta: Ghalia Indonesia.

Rivai, Veithzal. 2005. Manajemen Sumber Daya Manusia. Jakarta: Raja Grafindo Persada.

Rahman, A. (2021). PENGARUH HUBUNGAN INTERPERSONAL, LINGKUNGAN KERJA, DAN KECERDASAN EMOSIONAL TERHADAP KINERJA PEGAWAI PADA KANTOR KOMISI PEMILIHAN UMUM DAERAH (KPUD) KABUPATEN PARIGI MOUTONG. Jurnal Ekonomi Trend, 7(1), 58-70. https://doi.org/10.31970/trend.v7i1.173
Robbins, Stephen P. 2006. Perilaku Organisasi. Edisi kesepuluh. Jakarta: Indeks Kelompok Gramedia.

Setiyawan, Budi \& Waridin. 2006. Pengaruh Disiplin Kerja Karyawan dan Budaya Organisasi Terhadap Kinerja di Divisi Radiologi RSUP Dokter Kariadi Semarang. JRBI. Vol 2. No 2. Hal: 181-198.

Sugiyono, 2006. Metode Penelitian Bisnis. Bandung; CV. Alfabeta.

Sulistiyani, Ambar Teguh dan Rosidah. 2003. Manajemen Sumber Daya Manusia. Yogyakarta: Graha Ilmu.

Umar A, M. (2021). STRATEGI PEMASARAN DALAM UPAYA PENINGKATKAN VOLUME PENJUALAN PERUSAHAAN COMFORTA PALU. Jurnal Ekonomi Trend, 7(1), 27-40. https://doi.org/10.31970/trend.v7i1.171

Wahyuningrum, 2008. Hubungan Kemampuan, Kepuasan dan Disiplin kerja Dengan Kinerja Pegawai Di Kecamatan Tanggungharjo Kabupaten Grobogan. Tesis. Semarang: Program Pascasarjana Universitas Diponegoro.

Yani Handri Rumengan, 2013. Analisis Pengaruh Kepemimpinan, Lingkungan, Motivasi Dan Kemampuan Kerja Terhadap Kinerja Karyawan. Skripsi. Menado. Fakultas Ekonomi Universitas Sam Ratulangi. 